\title{
Stereotypes in Czech phraseology. Nations and ethnic groups*
}

\author{
Gutiérrez Rubio, Enrique \\ Palacký University, Olomouc, Czech Republic
}

\begin{abstract}
The starting point for this study is that (the majority of) conventional figurative units (CFUs) are conceptual in nature and that they somehow record and preserve the knowledge and even worldview of diverse cultures. The aim of this paper is to take a first step towards answering the question whether it is true not only that phraseology preserves the way a given culture understands the world (or understood it in the past), but if it works the other way round, i.e. if people using/knowing CFUs involving stereotypes - in this case, Czech idioms and collocations regarding nations and ethnic groups - tend to extend these stereotypes and attitudes beyond the linguistic sphere.

For this purpose a survey questionnaire was created, by means of which the stereotypes underlying a varied sample of 13 Czech CFUs were related to the prejudices of the respondents
\end{abstract}

\section{Keywords}

Czech phraseology, worldview, stereotypes, cognitive ethnolinguistics, nations, ethnic groups, Sapir-Whorf hypothesis.

\section{Introduction}

Studies of phraseology have been undergoing a revolution since the final years of the 20th century. The majority of the research is no longer based on the formal characteristics of idioms but on the meanings of conventional figurative expressions, their motivation and even evolution. This new cognitive-oriented approach - as proposed mainly by Dobrovol'skij and Piirainen (2005) - is the basis for my broad study of phraseological meaning in four European languages: Czech, English, German and Spanish. Nevertheless,

\footnotetext{
' I would like to gratefully acknowledge the financial support for this research provided by the ESF project Jazyková rozmanitost a komunikace - Language Diversity and Communication (registration number: CZ.1.07/2.3.00/20.0061). I would also like to thank the editors and anonymous reviewers of Topics in Linguistics for their helpful comments and suggestions on an earlier draft of the paper.
}

this paper focuses only on idioms and collocations regarding nations and ethnic groups in the Czech Republic.

From this new research perspective, and according to Kövecses (2002, p. 233), the meaning of an idiom is not arbitrary, but "arises from our more general knowledge of the world embodied in our conceptual system. In other words, idioms (or, at least, the majority of them) are conceptual, and not linguistic, in nature." Consequently, the cultural or "ethno" element plays a main role, since different cultural communities create and use different idioms, depending on their experiences and beliefs, in other words, on their particular worldview. In fact, this research agrees with the principles of socalled cognitive ethnolinguistics, according to which in phraseology - as well as in other linguistic fields, e.g. word meanings, word formation and text structure - can be found "traces of culture" in the sense of "the history and culture of specific communities, especially with the mentality of the group, its behaviours and value system" (Bartmiński, 
2009 , p. 10). In a similar vein Dobrovol'skij and Piirainen (2005, p. 251) state that "[C]onventional figurative units tend to absorb and accumulate cultural elements; permanent use of the CFUs hands these elements down and includes them into cultural memory" and Luque Durán (2009, p. $110)$ that phraseology is an "expression of the surrounding world projection in the mental universe $[. . .]^{\prime 2}$.

A key concept in this research is the stereotype, since in my opinion most of the idioms regarding nations and ethnic groups were created on this basis. Oakley (2000) argues that a stereotype is a global and generalizing image about a given social group based on incomplete realities. Following the theories of the French sociologist Bourdie, Mills (2008, p. 126) states that a stereotype occurs when "[...] some extreme perceived or imagined aspect of some members of an out-group's behaviour is hypothesised and then that feature is generalised to the group as a whole". On the other hand, following the cognitive ethnolinguist Zinken (2004, p. 116): "Stereotypes are not restricted to knowledge and opinions about members of social groups [...]. Rather, stereotyping is regarded as a general mechanism of organising knowledge about entities (objects, acts, relations) in the world. Thus, stereotypes are viewed as a chiefly cognitive phenomenon, with the evaluative function of enforcing in- and outgroups in the case of social stereotypes being secondary".

I found very inspiring material for this research in a peculiar request made in 2013 by the Casa de la Cultura Afrouruguaya ("House of Afrouruguayan Culture") to the Real Academia de la Lengua Española ("Royal Spanish Academy"). In a promotional video more than 20 Uruguayan personalities asked Real Academia to erase from its dictionary the idiom Trabajar como un negro "to work like a black (man)", since "it recalls a past of submission that should not be imposed again on any human being". ${ }^{3}$

\footnotetext{
2 "expresión de la proyección del mundoentorno en el universo mental [...]".

3 "evoca un pasado de sometimiento que no debería repetirse para ningún ser humano". Cf. "Borremos el racismo del lenguaje", Casa de la Cultura Afrouruguaya.

http://www.casaafrouruguaya.org/index.php /audio-visuales/videos/52mediateca/audiovisuales/399-video-3 [31/08/2013].
}

This well-intentioned action - although probably futile, since the Royal Academy does not include words and idioms in its dictionary on the basis of ethical considerations - implicitly states not only that phraseology preserves the way a given culture understands the world or understood it in the past - as proposed by cognitive ethnolinguistics - but the other way round, i.e., that if we use idioms, we may reproduce the underlying stereotypes and attitudes in society.

The aim of this paper is to take a first step towards answering the question whether people who use/know idioms involving stereotypes - in this case, Czech CFUs regarding nations and ethnic groups - tend to extend those stereotypes and attitudes beyond the linguistic sphere, i.e., to validate or refute the influence of CFUs on stereotypes. ${ }^{4}$ This hypothesis - as cognitive ethnolinguistics does in general (cf. Vaňková, 2010, p. 246) - takes us to a certain extent back to Humboldt's Weltansicht/Weltanschauung and especially to the tradition of the Sapir-Whorf doctrine of linguistic relativity. In encyclopaedias and general works it is common to find definitions such as the following: "The socalled Sapir-Whorf hypothesis holds that language plays a powerful role in shaping thought, perception, and action, especially in relation to the worldview of an associated culture" (McGee and Warms, 2013, p. 745). However, one of the main topics concerning this hypothesis is that it was never explicitly stated either by Edward Sapir or Benjamin Lee Whorf in any of their writings, which, as a matter of fact, they never co-authored. Consequently, definitions like the one quoted above are in fact mere generalizations of a much more complex question - as Lakoff $(1987$, p. 325) points out: "Whorf was not an easy person to classify. To think of him just as a relativist is much too simplistic".

Sapir, deeply influenced by his teacher Franz Boas, is generally associated with the socalled mild hypothesis. He in fact questions the oversimplification of one language representing one culture: "Totally unrelated languages share in one culture, closely related languages - even a single language -

${ }^{4}$ Similar research for Spanish phraseology can be found in Gutiérrez Rubio, 2013. I am not aware of any previous literature on Czech phraseology that had explored these units from a non-formal perspective. 
belong to distinct culture spheres" (Sapir, 1921 , p. 228). Nevertheless, in one of his most frequently quoted passages, from 1928, Sapir clearly subordinates worldview to language:

Human beings do not live in the objective world alone [...], but are very much at the mercy of the particular language which has become the medium of expression for their society. It is quite an illusion to imagine that one adjusts to reality essentially without the use of language and that language is merely an incidental means of solving specific problems of communication or reflection. The fact of the matter is that the 'real world' is to a large extent unconsciously built up on the language habits of the group. No two languages are ever sufficiently similar to be considered as representing the same social reality. The worlds in which different societies live are distinct worlds, not merely the same world with different labels attached [...] We see and hear and otherwise experience very largely as we do because the language habits of our community predispose certain choices of interpretation. (Sapir, 2008, pp. 221-222)

On the other hand, Sapir's pupil Whorf developed and radicalized this linguistic relativity to the extreme that language does not just influence the speaker's worldview, but that it determines his thoughts:

It was found that the background linguistic system (in other words, the grammar) of each language is not merely a reproducing instrument for voicing ideas but rather is itself the shaper of ideas, the program and guide for the individual's mental activity, for his analysis of impressions, for his synthesis of his mental stock in trade. [...] The categories and types that we isolate from the world of phenomena we do not find there because they stare every observer in the face; on the contrary, the world is presented in a kaleidoscopic flux of impressions which has to be organized by our minds-and this means largely by the linguistic systems in our minds. (Whorf, 1956, pp. 212-213)

Although a "modest version" of this linguistic relativity was often accepted by scholars (cf. Kay and Kempton, 1984), the strong version of the Sapir-Whorf hypothesis has been questioned and, in general, rejected and often even discredited (cf. Brown, 1976, p. 127ff.; Pinker, 1995, p. 57), to a great extent because of the scant evidence Whorf supported his claims with. Nevertheless, the quotes presented above are probably two of the most extreme expressions of their theories, as stated by Hill and Mannheim (1992,p.383): "Boas, Sapir, and Whorf were not relativists in the extreme sense often suggested by modern critics, but assumed instead a more limited position, recognizing that linguistic and cultural particulars intersect with universals". Almost from its beginning (cf. Lakoff, $1987)^{5}$, cognitive linguistics renewed interest in Whorf's theories by claiming that languages differ from each other in the way they conceptualize certain notions. Moreover, recent experimental evidence seems to prove the key role that language can play in shaping non-linguistic cognition, reopening debate about the so-called SapirWhorf hypothesis in the $21 \mathrm{st}$ century. Cognitively oriented authors such as Casasanto (2008), Boroditsky (2011a) and Fuhrman et al. (2011) analyse and discuss the conceptualization of time in different languages, proving, for instance, that Mandarin speakers "think about time vertically more often than English speakers do", which would suggest "that patterns in language and culture can induce differences in thought in even such fundamental conceptual domains as time" (Fuhrman et al., 2001 , p. 1325). In the same vein, Fausey et al. (2010) found that speakers of English and Japanese remember different things about the same events. The authors suggest that "our eye-witness memories for events are influenced by patterns in culture. Such cultural differences may be instantiated and supported by patterns in the languages we speak" (Fausey et al., 2010, p. 10). According to these authors, it is a matter of fact that language influences thought. Boroditsky (2011b, p. 65) goes even further by claiming that "[s]tudies have shown that changing how people talk changes how they think".

Finally, it has to be mentioned that many research studies of this nature have been performed in domains such as space, colour, number, and time (cf. Casasanto, 2008, p. $69 \mathrm{ff}$.). However, I am not aware of any study of this nature based on CFUs.

In this paper, the aim is to take a first step towards finding an answer to the question of whether it is true that people who use/know

\footnotetext{
5 "All too often, arguments against Whorf are taken to be arguments against relativism in general. And arguments against Whorf [...] may not be arguments against the position that Whorf advocated" (Lakoff, 1987, p. 328).
} 
CFUs involving stereotypes tend to extend these stereotypes and attitudes beyond the linguistic sphere. In this specific case, the analysis will focus on Czech idioms and collocations regarding nations and ethnic groups.

\section{Methodology of research}

In order to perform this first approximation to the validation or not of the influence of CFUs on stereotypes, a survey questionnaire was created, by means of which the stereotypes underlying a sample of 13 Czech CFUs were related to the prejudices of the respondents. This small sample (see Table 1) was formed from a group of CFUs in which a nation or ethnic group is explicitly named, all excerpted from two of the four volumes of the most extensive Czech phraseological dictionary (Čermák, 2009a; 2009b). ${ }^{6}$ The expressions were chosen according to one main factor - the set of CFUs should be as diverse as possible. The methodological motivation for this idea was to test whether there are significant divergences in the answers of the respondents depending on three factors:

Opaqueness vs. transparency of the expressions.

Often-used vs. archaic expressions.

Idioms vs. figurative collocations. ${ }^{7}$

\begin{tabular}{|l|l|}
\hline Czech CFU & English version/translation \\
\hline $\begin{array}{l}\text { Americký způsob } \\
\text { života }\end{array}$ & American way of life \\
\hline Zmizet po anglicku & Take French leave \\
\hline Skotská šetrnost & Cheese-paring meanness \\
\hline Francouzská nemoc & French disease \\
\hline $\begin{array}{l}\text { (jednou) za uherský } \\
\text { rok }\end{array}$ & Once in a blue moon \\
\hline Být pro někoho & Be all Greek to someone \\
\hline
\end{tabular}

${ }^{6}$ Other stereotypes regarding nations and ethnic groups in European languages can be found in Pajdzińska (2007) and Klimová and Manai (2009).

${ }^{7}$ I would like to express my gratitude to my students of the courses Úvod do kognitivni lingvistiky "Introduction to Cognitive Linguistics" (academic year 2012/13) and Frazeologie a obraz světa "Phraseology and Worldview" (2013/2014) for helping me to choose the CFUs and to prepare the Czech survey questionnaire, as well as for spreading it among their relatives and friends.

8 When possible, the Czech units were translated into similar English idioms and collocations, often extracted from Čermák (2009a; 2009b).

\begin{tabular}{|l|l|}
\hline španělskou vesnicí & \\
\hline Tvrdé české palice & "Stubbornness" \\
\hline $\begin{array}{l}\text { Hospodařit } \\
\text { turecky/po turecku }\end{array}$ & "Manage chaotically" \\
\hline Cikánská krev & Gypsy blood \\
\hline Cikánský lágr & "Pigsty" \\
\hline Kanadský žert/žertík & Dirty trick; horse-play \\
\hline $\begin{array}{l}\text { Zachovat anglický } \\
\text { klid }\end{array}$ & "Sang-froid"; "phlegmatism" \\
\hline Anglický trávník & $\begin{array}{l}\text { "Smooth lawn/turf"; "a } \\
\text { perfect lawn" }\end{array}$ \\
\hline
\end{tabular}

Table 1. Czech CFUs featuring nations and ethnic groups

Now the question arises as to how to "extract" the stereotypes underlying the CFUs in the most systematic way possible. In order to achieve this goal I make use inspired by what Lakoff (1987) called the propositional Idealized Cognitive Model and Fillmore (2006) a Frame - of the notion of Conceptual Stereotype in Focus.

Arguing in the same vein as other cognitively oriented scholars, I believe that most of the CFUs are conceptually based on stereotypes - some of them are "alive" these days, some of them not any more. The English expression Not for all the tea in China, for instance, was constructed on the basis of the belief (correct or not, it makes no difference) that the Chinese drink and produce a huge amount of tea. This is far from the only idea that the Western civilizations share about the Chinese people, e.g. that they eat (and, logically, produce) rice, are yellow-skinned, practise martial arts, ride bikes, speak a strange language, write in incomprehensible characters, produce porcelain (metonymically called china in English) and are communist. ${ }^{9}$ From all the stereotypes that a given cultural community connects (or has connected in its history) with a specific concept - in this case a nation or ethnic group - only some of them became phraseologized. I am not aware of any CFU in the languages in question concerning the belief that the Chinese are communist or that they practise martial arts, but expressions regarding the remaining stereotypes mentioned above do exist. And, what is more, CFUs often "hide" other beliefs that nowadays have disappeared or, at least,

${ }^{9}$ Nevertheless, stereotypes change with time and in these first years of the 21 st century because of the enormous social transformations that are taking place in the country - we are starting to perceive Chinese society as very consumerist, as was expressed by some of the respondents to the questionnaire. 
are not as "active" as the ones presented above, e.g. the stereotypes Chinese people are naïve and Chinese people work patiently (see Engañar como a un chino and Trabajar como un chino in Table 2).

To sum up, most of the CFUs are based on stereotypes shared by a representative part of a given cultural community. Nevertheless, generally just one of the characteristics prototypically linked to the element in question - in this case a group of persons, such as the Chinese nation/race - is activated in a specific CFU. This specific and single conceptual mapping is what will be called Conceptual Stereotype in Focus (CSiF) in this study. In Table 2, some CSiFs regarding Chinese people in English, Spanish and German phraseology can be observed.

\begin{tabular}{|l|l|l|}
\hline \multicolumn{1}{|c|}{ CFU } & \multicolumn{1}{|c|}{ English translation } & \multicolumn{1}{|c|}{ CSiF } \\
\hline $\begin{array}{l}\text { (English) Would not do sth for all the } \\
\text { tea in China (CIDI, p. 384) }\end{array}$ & - & $\begin{array}{l}\text { The Chinese drink/produce a } \\
\text { great deal of tea }\end{array}$ \\
\hline $\begin{array}{l}\text { (English) be like a bull in a china shop } \\
\text { (CIDI, p. 53) }\end{array}$ & - & The Chinese produce porcelain \\
\hline $\begin{array}{l}\text { (German) Ob/wenn in China ein } \\
\text { Fahrrad/Sack Reis umfält (DUDEN 11, } \\
\text { p. 153) }\end{array}$ & $\begin{array}{l}\text { "Nothing important happens" (lit. } \\
\text { If/when in China a bike/sack of rice } \\
\text { fells) }\end{array}$ & $\begin{array}{l}\text { The Chinese have/produce a } \\
\text { great deal of bikes/rice }\end{array}$ \\
\hline $\begin{array}{l}\text { (Spanish) Hablar en chino / Sonar a } \\
\text { chino (DFEA, p. 275) }\end{array}$ & $\begin{array}{l}\text { Be all Greek to someone (lit. to } \\
\text { speak in Chinese / to sound } \\
\text { Chinese) }\end{array}$ & $\begin{array}{l}\text { The Chinese language is } \\
\text { incomprehensible }\end{array}$ \\
\hline $\begin{array}{l}\text { (Spanish) Trabajar como un chino / } \\
\text { (ser) trabajo de chinos (DFEA, p. 275) }\end{array}$ & $\begin{array}{l}\text { To work patiently / (to be) a very } \\
\text { detailed piece of work (lit. to work } \\
\text { like a Chinese / Chinese work) }\end{array}$ & The Chinese work patiently \\
\hline $\begin{array}{l}\text { (Spanish) Engañar como a un chino } \\
\text { (DFEA, p. 275) }\end{array}$ & $\begin{array}{l}\text { "To fool someone completely" (lit. } \\
\text { to fool someone like a Chinaman) }\end{array}$ & The Chinese are naïve \\
\hline $\begin{array}{l}\text { (Spanish) Amarillo como un chino / } \\
\text { Más amarillo que un chino } 0\end{array}$ & $\begin{array}{l}\text { "Very yellow" (lit. As yellow as a } \\
\text { Chinaman/ yellower than a } \\
\text { Chinaman) }\end{array}$ & The Chinese are yellow-skinned \\
\hline
\end{tabular}

Table 2. Some CSiFs regarding Chinese people in European phraseology.

10 Spanish phraseological dictionaries do not include this simile. Nevertheless, it is quite commonly used in current Spanish and it is documented at least once in the Spanish corpus CREA (Corpus del español actual): "y me puse más amarillo que un chino y muy debilitado". (cf. http://corpus.rae.es/).

It is necessary to recognize the hard task that it sometimes is to obtain the CSiF for the CFUs shown in Table 3. This question was discussed with my Czech students for several hours. We based our decisions not just on their competence as native speakers but also on taking into account the information included in the dictionaries (Čermák, 2009a; 2009b) and the contexts of use of the expressions under scrutiny in the Czech National Corpus." Nevertheless, it has to be admitted that some of them can be questionable.

\begin{tabular}{|l|l|l|}
\hline \multicolumn{1}{|c|}{ Czech CFU } & \multicolumn{1}{c|}{ Nation } & \multicolumn{1}{c|}{ CSiF } \\
\hline $\begin{array}{l}\text { Americký } \\
\text { způsob života }\end{array}$ & American & Consumerist \\
\hline $\begin{array}{l}\text { Zmizet po } \\
\text { anglicku }\end{array}$ & English & Discretion, tact \\
\hline $\begin{array}{l}\text { Skotská } \\
\text { šetrnost }\end{array}$ & Scottish & Thrift \\
\hline $\begin{array}{l}\text { Francouzská } \\
\text { nemoc }\end{array}$ & French & Sexuality \\
\hline
\end{tabular}

${ }^{11}$ cf. https://www.korpus.cz/.

\begin{tabular}{|l|l|l|}
\hline $\begin{array}{l}\text { (jednou) za } \\
\text { uherský } \\
\text { mésíc/rok }\end{array}$ & Hungarian & Cannot be trusted ${ }^{12}$ \\
\hline $\begin{array}{l}\text { Být pro někoho } \\
\text { spanělskou } \\
\text { vesnicí }\end{array}$ & Spanish & Incomprehensible \\
\hline $\begin{array}{l}\text { Tvrdé české } \\
\text { palice }\end{array}$ & Czech & $\begin{array}{l}\text { Hard- } \\
\text { headed/stubborn }\end{array}$ \\
\hline $\begin{array}{l}\text { Hospodarit } \\
\text { turecky/po } \\
\text { turecku }\end{array}$ & Turkish & Chaotic \\
\hline Cikánská krev & Gypsy & Uncontrollability \\
\hline Cikánský lágr & Gypsy & Untidy, dirty \\
\hline $\begin{array}{l}\text { Kanadský } \\
\text { žert/žertík }\end{array}$ & Canadian & Malicious \\
\hline $\begin{array}{l}\text { Zachovat } \\
\text { anglický klid }\end{array}$ & English & Phlegmatic \\
\hline
\end{tabular}

12 The CSiF "Cannot be trusted" is probably the most questionable of all. It is based on the information given by Čermák (2009a, p. 176). According to this, Czech soldiers sent to fight with the Hungarians against the Turks for a fixed time period were often forced to prolong their stay in the army: " $V$ době tureckých válek byli vojáci najímáni do služby v Uhrách na urč. dobu, avšak ta se stále prodlužovala". 


\begin{tabular}{|l|l|l|}
\hline $\begin{array}{l}\text { Anglický } \\
\text { trávník }\end{array}$ & English & Careful, meticulous \\
\hline
\end{tabular}

Table 3. CSiFs extracted for Czech CFUs regarding nations and ethnic groups.

It is interesting to note that some expressions, although sharing a common origin, can have different meanings in two languages. It would be the case of Americky zpưsob života, which, in Czech, focuses on a consumerist way of living, unlike the original expression in English, which is related to other values, such as individualism and freedom.

Once the CSiFs were clear, I was able to prepare the survey questionnaire. ${ }^{13}$ It was divided into three parts.

In the introduction the instructions ${ }^{14}$ were given and then followed by three simple questions:

- The age of the respondent.

- If he/she has lived in a foreign country for longer than three months.

- If he/she has personal relationships with members of other cultures. ${ }^{15}$

In the second section, the respondents were asked about their stereotypes by using the following formulation: "Which of the following nations or ethnic groups..." plus the CSiF as, for instance, "...are consumerist" or "...have discretion/tact"? Up to three answers were permitted.

In the third and last part of the survey questionnaire, a question was finally asked about the use/knowledge of the CFUs in question. The respondents were asked to grade them from 0 to 3 ( 0 - I have never heard of that; 1 - I know it, but I never use it actively; 2 - I know it and I have used it sometimes; 3 - I use it frequently).

It is important to comment that once the respondents reached the third part of the survey questionnaire they could not go back and change their answers to the second part.

\section{Results of the survey questionnaires}

Before the results of the survey questionnaires are presented, some socio-

13 For its elaboration I followed the guidelines and ethical standards presented and discussed in Valeš (2010). The complete survey questionnaire is included in an appendix at the end of this paper.

${ }_{14}^{14}$ Without any references to phraseology or even linguistics, in order not to influence the respondents' answers.

${ }^{15}$ By formulating these last two questions I tried to avoid possible interference. demographic information should be offered. Probably because the majority of the respondents used the online questionnaire, ${ }^{16}$ the sample population was composed mainly of young respondents $(72.1 \%$ - 16 to 30 years old). Logically, the number of members of the sample population older than 31 was lower $(17.1 \%-31-54 ; 10.8 \%$ $55+)$. The survey questionnaire was long, since it was formed of three parts and 29 tasks. In order to limit the number of questions, no other variables, such as the gender or educational level of the respondents, were included.

From the almost 250 survey questionnaires received, just 159 were accepted, since the remaining ones were left significantly or completely blank.

The research hypothesis is that people who use/know CFUs involving stereotypes tend to extend these stereotypes and attitudes beyond the linguistic sphere. Consequently, it is expected that the average levels of use/knowledge will be lower for those respondents who did not match the answer in the second section of the survey questionnaire (see the fifth column of Tables 4 and 6, "Average use/knowledge. Nonmatching answers (0-3)") and higher for those who did match the answer (see the fourth column), that is to say, higher for those who marked the nation or ethnic group related to the CFU on which the question is based, such as "Scottish" when they were asked about "Thrift". ${ }^{17}$ Finally, in the last column of Tables 4 and 6 the difference in use/knowledge is shown, i.e. the average levels of use/knowledge for matching answers minus the one for nonmatching answers. If this number is positive (see Table 4), the hypothesis is supported, since it would show that people marking the "expected" nation or ethnic group are precisely those who on average use the CFU more frequently (or at least who are more familiar with it). On the contrary, if the

\footnotetext{
${ }^{16}$ Cf. http://www.e-encuesta.com/.

17 The second and third columns show the total number of respondents that matched and did not match the answers. These data are interesting because they show to what extent Czechs relate the CSiF to the nations or ethnic groups they are based on. Nevertheless, it is not as relevant for this research as the next columns, where, as already mentioned, the average levels of use/knowledge are presented.
} 
number is negative (see Table 6) the hypothesis is rejected.

Table 4 includes those eight expressions in which the average numbers for use/knowledge are higher for those respondents who marked the "expected" answer than for those who did not. The CFUs are ordered according to the difference between the average numbers for matching and non-matching answers (see last column of table 4). Although all of them show an increase in the average numbers for the matching answers, these differences are not equal, being relatively high in some cases CFUs (1), (2) and even (3) - and in the majority of them very low - (4) to (8).

\begin{tabular}{|l|c|c|c|c|c|}
\hline \multicolumn{1}{|c|}{ CFU } & $\begin{array}{c}\text { Number of } \\
\text { matching } \\
\text { answers }\end{array}$ & $\begin{array}{c}\text { Number of } \\
\text { non-matching } \\
\text { answers }\end{array}$ & $\begin{array}{c}\text { Average use/ } \\
\text { knowledge. } \\
\text { Matching } \\
\text { answers (0-3) }\end{array}$ & $\begin{array}{c}\text { Average } \\
\text { use/knowledge. } \\
\text { Non-matching } \\
\text { answers (0-3) }\end{array}$ & $\begin{array}{c}\text { Difference in } \\
\text { use/ knowledge }\end{array}$ \\
\hline $\begin{array}{l}\text { (1) Skotská } \\
\text { šetrnost }\end{array}$ & 33 & 125 & 1.33 & 0.32 & +1.01 \\
\hline $\begin{array}{l}\text { (2) Zachovat } \\
\text { anglický klid }\end{array}$ & 63 & 94 & 1.54 & 0.80 & $+\mathbf{0 . 7 4}$ \\
\hline $\begin{array}{l}\text { (3) Americký } \\
\text { zpưsob života }\end{array}$ & 138 & 18 & 1.72 & 1.33 & $+\mathbf{0 . 3 9}$ \\
\hline $\begin{array}{l}\text { (4) Cikánská krev } \\
\text { (5) Francouzská } \\
\text { nemoc }\end{array}$ & 48 & 109 & 1.29 & 0.13 & $+\mathbf{0 . 1 6}$ \\
\hline $\begin{array}{l}\text { (6) Cikánský lágr } \\
\text { (7) Tvrdé české } \\
\text { palice }\end{array}$ & 123 & 90 & 0.28 & 0.49 & $+\mathbf{0 . 1 4}$ \\
\hline $\begin{array}{l}\text { (8) Zmizet po } \\
\text { anglicku }\end{array}$ & 92 & 135 & 1.15 & 1.09 & $+\mathbf{0 . 0 6}$ \\
\hline
\end{tabular}

Table 4. CFUs with positive values for Difference in use/knowledge.

The data in Table 4 speak for a tendency to relate active stereotypes and the use (or at least the knowledge) of the CFUs underlying these stereotypes. It is especially clear in (1), since the respondents who marked "Scottish" on average clearly knew the CFU (1.33). On the other hand, the average respondent who did not mark "Scottish" in the questionnaire had not heard of the expression (0.32). The difference of 1.01 points between both results seems to be high, considering that we are dealing with a short scale (0-3). Nevertheless, a statistical analysis of the data is required to be in a position to state that the results are statistically significant.

A chi-square goodness of fit test ${ }^{18}$ relating observed values and expected values was applied to determine whether the observed distributions are significant or not. Two categories were established - one for data regarding matching answers and one for non-matching answers. The observed values were obtained by multiplying the number of matching/non-matching answers for the average use/knowledge of each type of

18 An online calculator was used for this purpose:

http://www.socscistatistics.com/tests/goodn essoffit/default2.aspx category. In the case, for instance, of (1) Skotská setrnost (see Table 4), the observed value was $44(33 * 1.33)$ for matching answers and $40(125 * 0.32)$ for non-matching answers. For the expected values the average use/knowledge of all 159 valid answers was taken into account without considering whether the answers matched or not, since it is "expected" that use/knowledge of a CFU has no influence on the speaker's stereotypes. In the specific case of Skotská setrnost the average value was 0.531 and, as a consequence of this, the expected value turned out to be $18\left(33^{*} 0.531\right)$ for the matching answers and $66(125 * 0.531)$ for the non-matching answers. ${ }^{19}$ According to this, the chi-square value would be 47.798 (see Table 5), which implies that the P-Value is $<0.001$ and the result is significant at $\mathrm{p}=\leq 0.05$, i.e., the results for Skotská šetrnost are statistically relevant.

\footnotetext{
19 I am aware that this kind of procedure is probably not optimal for running a 2-factor analysis. Nevertheless, this is just an exploratory statistical analysis suitable for a pilot experiment like the one presented here.
} 


\begin{tabular}{|l|c|c|c|c|c|}
\hline & Observed & Expected & Difference & Difference Sq. & Diff. Sq. / Exp Fr. \\
\hline Matching answers & 44 & 18 & 26.00 & 676.00 & 37.56 \\
\hline $\begin{array}{l}\text { Non-matching } \\
\text { answers }\end{array}$ & 40 & 66 & -26.00 & 676.00 & 10.24 \\
\hline chi-square value & & & & & $\mathbf{4 7 . 7 9 8}$ \\
\hline
\end{tabular}

Table 5. Calculation of the chi-square value for the CFU Skotská šetrnost

After the same calculation had been applied to all CFUs with positive values for difference in use/knowledge it was determined that the observed distribution is significant in two out of the eight CFUs that were analysed for Skotská šetrnost and Zachovat anglický $k l i d^{20}$ - but not significant for the rest. ${ }^{21}$

${ }^{20}$ The chi-square value is 18.974 ; the $\mathrm{P}$-Value is $<0.001$; and the result is significant at $\mathrm{p}=\leq 0.05$.
Next, in Table 6 the data regarding the CFUs with negative values are shown, i.e., those refuting the main hypothesis of this paper.

21 The chi-square values are situated in a range between 3.394 and 0.022 ; the P-Value between 0.065 and 0.882 ; and the results are not significant at $\mathrm{p}=\leq 0.05$.

\begin{tabular}{|l|c|c|c|c|c|}
\hline \multicolumn{1}{|c|}{ CFU } & $\begin{array}{c}\text { Number of } \\
\text { matching } \\
\text { answers }\end{array}$ & $\begin{array}{c}\text { Number of } \\
\text { non-matching } \\
\text { answers }\end{array}$ & $\begin{array}{c}\text { Average use/ } \\
\text { knowledge. } \\
\text { Matching answers } \\
\mathbf{( 0 - 3 )}\end{array}$ & $\begin{array}{c}\text { Average } \\
\text { use/knowledg } \\
\text { e. Non- } \\
\text { matching } \\
\text { answers (0-3) }\end{array}$ & $\begin{array}{c}\text { Difference in } \\
\text { use/ } \\
\text { knowledge }\end{array}$ \\
\hline $\begin{array}{l}\text { (1) Kanadský } \\
\text { žert/žertík }\end{array}$ & 8 & 150 & 2.25 & 2.48 & -0.23 \\
\hline $\begin{array}{l}\text { (2) Jednou za } \\
\text { uherský mésíc/rok }\end{array}$ & 10 & 149 & 2.50 & 2.71 & -0.21 \\
\hline (3) Anglický trávník & 59 & 98 & 2.10 & 2.22 & -0.12 \\
\hline $\begin{array}{l}\text { (4) Hospodařit } \\
\text { turecky/po turecku }\end{array}$ & 18 & 141 & 0.50 & 0.62 & -0.12 \\
\hline
\end{tabular}

Table 6. CFUs with negative values for Difference in use/knowledge.

The statistical analysis of the numbers regarding these 4 CFUs proves that all these "negative values" are not significant. ${ }^{22}$

Moreover, one CFU (Být španělskou vesnicí) is invalid for the purposes of this research since not a single respondent marked the "expected answer". It can probably be explained by the fact that the link to the motivation of the expression became lost with time, as a result of which the CFU would not be transparent for Czech speakers any more, probably since for centuries now Spanish has not been the archetype of an incomprehensible, somehow imposed language that it used to be in the times of the "Spanish" Habsburg king Charles V (cf. Čermák, 2009b, p. 867).

Next, the variable age will be taken into account. Because of the abovementioned unbalanced character of the respondents, they have been divided into just two groups. Group (a) consists of the respondents between 16 and 30 years ( 115 respondents -

22 The chi-square values are situated in a range between 0.211 and 0.112 , the P-Value between 0.646 and 0.738 , and the results are not significant at $p=\leq 0.05$.
72.3\%). Group (b) includes all the respondents above 30 years (44 respondents - 27.7\%).

When the chi-square goodness of fit test was applied to Group (b), just one CFU produced a significant result - Skotská šetrnost ${ }^{23}$. On the contrary, in relation to the youngest group of respondents there are four CFUs that, according to the chi-square goodness of fit test, are statistically relevant. Together with Skotská šetrnost ${ }^{24}$ and Zachovat anglický klid, ${ }^{25}$ two more CFUs are proven to

${ }^{23}$ The chi-square value is 5.63 , the P-Value is 0.018 , and the result is significant at $\mathrm{p}=\leq 0.05$.

${ }^{24}$ The chi-square value is 34.554 , the P-Value is $<0.001$, and the result is significant at $\mathrm{p}=\leq 0.05$.

${ }^{25}$ The chi-square value is 13.511 , the $P$-Value is $<0.001$, and the result is significant at $\mathrm{p}=\leq 0.05$. 
be significant - Americký způsob života ${ }^{26}$ and Francouzská nemoc ${ }^{27}$.

This would slightly reinforce the hypothesis proposed in this paper that people who know a CFU or use it more often tend to reproduce the underlying stereotypes and attitudes in society.

${ }^{26}$ The chi-square value is 3.907 , the P-Value is 0.048 , and the result is significant at $\mathrm{p}=\leq 0.05$.

${ }_{27}$ The chi-square value is 5.625 , the P-Value is 0.018 , and the result is significant at $\mathrm{p}=\leq 0.05$.
Now the question arises why four CFUs turned out to be statistically significant among the people under 31 (Group [a]) and just one among the older respondents (Group [b]). The answer lies in the difference between matching and non-matching answers. So, when the values documented for Group (a) and Group (b) are compared in Table 7, the difference regarding the four CFUs in question (in bold in the table) is always greater for the younger respondents - for instance, from 0.80 to 0.99 for Skotská šetrnost.

\begin{tabular}{|c|c|c|c|c|c|c|}
\hline \multirow[t]{2}{*}{ CFU } & \multicolumn{2}{|c|}{$\begin{array}{c}\text { Group (b) } \\
\text { Average use/knowledge }\end{array}$} & \multicolumn{2}{|c|}{$\begin{array}{c}\text { Group (a) } \\
\text { Average } \\
\text { use/knowledge }\end{array}$} & \multicolumn{2}{|c|}{$\begin{array}{c}\text { Difference } \\
\text { between } \\
\text { matching and } \\
\text { non- matching } \\
\text { answers }\end{array}$} \\
\hline & $\begin{array}{c}\text { Matching } \\
\text { answers (0- } \\
3)\end{array}$ & $\begin{array}{c}\text { Non- } \\
\text { matching } \\
\text { answers (0- } \\
3) \\
\end{array}$ & $\begin{array}{c}\text { Matching } \\
\text { answers } \\
(0-3)\end{array}$ & $\begin{array}{c}\text { Non- } \\
\text { matching } \\
\text { answers } \\
(0-3) \\
\end{array}$ & $\begin{array}{l}\text { Group } \\
\text { (b) }\end{array}$ & $\begin{array}{l}\text { Group } \\
\text { (a) }\end{array}$ \\
\hline (1) Skotská šetrnost & 1.50 & 0.70 & 1.21 & 0.22 & 0.80 & 0.99 \\
\hline (2) Zachovat anglický klid & 1.78 & 1.22 & 1.40 & 0.68 & 0.56 & 0.72 \\
\hline (3) Americký způsob života & 1.37 & 1.75 & 1.84 & 1.00 & -0.38 & 0.84 \\
\hline (4) Cikánská krev & 1.07 & 1.22 & 1.35 & 1.13 & -0.15 & 0.22 \\
\hline (5) Francouzská nemoc & 0.28 & 0.29 & 0.27 & 0.08 & -0.01 & 0.19 \\
\hline (6) Cikánský lágr & 0.71 & 0.43 & 0.54 & 0.48 & 0.28 & 0.06 \\
\hline (7) Tvrdé české palice & 2 & 1.44 & 1.11 & 0.93 & 0.56 & 0.18 \\
\hline (8) Zmizet po anglicku & 1.28 & 1.22 & 1.17 & 1.13 & 0.06 & 0.04 \\
\hline (9) Kanadský žert/žertík & 2.5 & 2.26 & 2.17 & 2.56 & 0.24 & -0.39 \\
\hline (10) Jednou za uherský měsíc/rok & 3 & 2.37 & 2.29 & 2.83 & 0.63 & -0.54 \\
\hline (11) Anglický trávník & 1.92 & 2.28 & 2.15 & 2.02 & -0.36 & 0.13 \\
\hline $\begin{array}{l}\text { (12) Hospodařit turecky/po } \\
\text { turecku }\end{array}$ & 1 & 1.18 & 0.25 & 0.39 & -0.18 & -0.14 \\
\hline
\end{tabular}

Table 7. Average use/knowledge for matching and non-matching answers according to the age of the respondents

In addition to this, in these CFUs it can be observed that there is a general decrease in the values in Group (a) with respect to Group (b) regarding both matching and nonmatching answers, that is, the younger generation seems to know/use these CFUs less than the older one. ${ }^{28}$ Nevertheless, this reduction is unbalanced, i.e., the decrease in "use/knowledge" for non-matching answers is larger in all four cases than the one for matching answers. For instance, in the case of Skotská šetrnost a divergence of 0.48

${ }^{28}$ However, this is not the case for Americky způsob żivota, for which the average use/knowledge, including matching and non-matching answers, is 1.76 for Group (a) and 1.44 for Group (b). points (from 0.70 to 0.22 ) is documented for non-matching answers and 0.29 (from 1.50 to 1.21) for matching answers. In other words, these numbers show that the gap between knowing/using and not knowing/using a CFU is not just larger for the members of Group (a) than for those of Group (b) but that this gap is mainly caused by the lower values documented for nonmatching answers. All this speaks not just for the fact that the younger generation knows or uses these CFUs less, but that they are more strongly influenced by their knowledge/use than older people. It is not possible to give a conclusive reason for this, but it could be suggested that the scale of values of the members of Group (a) is less established than that of Group (b) or even 
that the stereotypes in which the CFUs are conceptually based (see Section 1 of this paper) are getting lost with time in the society and increasingly kept alive exclusively in the lexicalized expressions.

Unfortunately, the data supporting this theory are not valid for all CFUs, as can be observed in Table 7. Moreover, this hypothesis cannot be conclusively stated because of the small number of respondents above 30 years (for instance, in CFUs (7), (9), and (10) the number of respondents that marked the "expected" answer is very low three or less). Logically, a further study, one that is more balanced regarding the age of the respondents, has to be performed.

\section{Conclusions and further research}

After the analysis of the data obtained from 159 valid survey questionnaires, it can be concluded that people who use a CFU more frequently (or at least who are more familiar with it) tend to connect the nation or ethnic group with the underlying stereotype more frequently than people who use or know it less. It was proven for $66.6 \%$ of the CFUs analysed (8 out of a total of 12). Nevertheless, the chi-square goodness of fit test showed that the observed distribution is significant only in two of the 12 CFUs, both supporting the main hypothesis of this research (four out of 12 for the youngest segment of respondents).

It has to be admitted that the data obtained in this first approach to the topic are not conclusive and, consequently, it cannot be stated that our view of the world is generally influenced by the CFUs we know/use. Nevertheless, this research shows that sometimes people who use/know idioms involving stereotypes significantly extend those stereotypes and attitudes beyond the linguistic sphere, since the only two CFUs (out of 12 valid ones) with a significant distribution are expressions in which the average numbers for use/knowledge are higher for those respondents who marked the "expected" answer than for those who did not (four CFUs for respondents younger than 31 ).

Cognitive ethnolinguists argue that the mentality, behaviours and value system of a given cultural group somehow linger in phraseology. To this we could probably add that the stereotypes preserved in CFUs can sometimes influence the values of the people who use them. According to the results of the survey questionnaires offered above, the respondents who know well the
CFUs Skotská šetrnost and Zachovat anglický klid or even use them (in both cases with average numbers close to 1.5 (see Table 4), i.e., between 1 "I know it, but I never use it actively" and 2 "I know it and I have used it sometimes"), relate Scottish people to "Thrift" and the English to "Discretion, tact" significantly more often than those respondents who, on average, do not use these CFUs or know them vaguely (with average numbers between 0 "I have never heard of that" and 1 "I know it, but I never use it actively"). ${ }^{29}$

Since the respondents answered about stereotypes in the first place (and only after that about their knowledge/use of the CFUs) and the chi-square goodness of fit test confirmed that these distributions are statistically significant, the only plausible explanation for these facts is that in some cases CFUs regarding nations and ethnic groups do influence our stereotypes about them, i.e., that CFUs can shape what we think about other people. As a result, I have to agree with the main thought of the House of Afrouruguayan Culture, since the use of an expression could reinforce racial stereotypes (or prejudices) regarding a nation or ethnic group. ${ }^{30}$

In total, the findings presented in this paper, although tentative, seem to reinforce the idea - lately renewed among cognitively oriented linguists - that to some extent language does influence non-linguistic cognition, i.e., that even if language does not determine the way we think, it "shapes" it.

Nevertheless, we are dealing here with a pilot study and, consequently, further and more comprehensive research should be carried out in the future, in order to completely validate the influence of CFUs on stereotypes or at least to understand in which cases this influence is or is not significant. Survey questionnaires have been

${ }^{29}$ The same can be stated for "Consumerist" and Americký zpuisob života, and for "sexuality" and Francouzská nemoc among the respondents between 16 and 30 years, although in these cases Americký zpursob života is well known to all the respondents 1.00 for Group (a) and 1.75 for Group (b) and, on the contrary, Francouzská nemoc is almost unknown for both groups -0.08 and 0.29 , respectively.

${ }^{30}$ I think that erasing expressions from the dictionary is not the way to meet this challenge, though. 
proven to provide researchers with valuable data; nevertheless, more solid experimental data supporting this theory need to be obtained. Consequently, the next step will focus on measuring automatic biases by carrying out non-linguistic tests. Unfortunately, unlike space, colour, number or time, it is very difficult to test a population's stereotypes in relation to CFUs without verbal interaction. Logically, a mixed experiment will be conducted. In this case the participants will not be asked directly about their stereotypes. Instead, a series of sketches of persons without any racial characteristics symbolizing the Conceptual Stereotypes in Focus related to CFUs will be shown to them; for instance, a sketch of a person going into a shop and then coming out holding shopping bags for Americký zpưsob života. ${ }^{31}$ In this first task the

31 Since some of the CFUs are almost impossible to represent, only a number of them will be the objects of this experiment and only after it has been proven that the pictures do indeed symbolize the CFUs in question. participant will have to relate these pictures with series of sketches symbolizing stereotyped persons of diverse nations and ethnic groups. In a second task, questions about the use/knowledge of the CFUs will be shown, in this case expressed verbally and with a numerical scale similar to the one used for this pilot study (0-3). Moreover, the ages of the respondents will be balanced, so that the highest influence of the CFUs among the younger generation of speakers partially observed in this analysis will be confirmed or rejected.

By means of this second and more precise analysis, in which some of the problems experienced in this first study will be avoided, the aim will be to prove conclusively whether phraseology does or does not play a role in adult human thinking and, in particular, in shaping people's nonlinguistic stereotypes.

\section{References}

BARTMINSSKI, J., 2009. Aspects of cognitive ethnolinguistics. London and Oakville, CT.: Equinox.

BORODITSKY, L., 2011 a. How languages construct time. In: S. Dehaene and E. Brannon eds. Space, time and number in the brain. Searching for the foundations of mathematical thought. Amsterdam: Elsevier, p. 333-341.

BORODITSKY, L., $2011 \mathrm{~b}$. How language shapes thought. The languages we speak affect our perceptions of the world. Scientific American Magazine February 201 1, p. 63-65.

ČERMÁK, F., et al., 2009a. Slovník české frazeologie a idiomatiky. 2. Výrazy neslovesné. Praha: Leda.

ČERMÁK, F., et al., 2009b. Slovník české frazeologie a idiomatiky. 3. Výrazy slovesné. Praha: Leda.

DOBROVOL'SKIJ, D. and PIIRAINEN, E., 2005. Figurative language. Amsterdam: Elsevier.

FAUSEY, C. M., LONG, B. L. INAMORI, A., and LERA BORODITSKY., 2010. Constructing agency: the role of language. Frontiers in Psychology 1:162. doi: 10.3389/ fpsyg.2010.00162.

FILLMORE, C. J., 2006. Frame semantics. In: D. Geeraerts, ed. Cognitive linguistics: basic readings. Berlin and New York: Mouton de Gruyter, pp. 373-400.

FUHRMAN, O., MCCORMICK, K., CHEN, E., JIANG, H. SHU, D., MAO, S., and BORODITSKY, L., 2011 . How linguistic and cultural forces shape conceptions of time: English and Mandarin time in 3D. Cognitive Science, vol. 35, pp. 1305-1328.

GUTIÉRREZ RUBIO, E., 2013. Fraseología y estereotipos en español. ¿Una relación bidireccional? Language Design, vol. 15, pp. 119-136.

HILL, J. H. and MANNHEIM, B., 1992. Language and world view. Annual Review of Anthropology, vol. 21, pp. 381-406.

KAY, P. and KEMPTON, W., 1984. What is the Sapir-Whorf hypothesis? American Anthropologist, vol. 86, no. 1, pp. 65-79.

KLIMOVÁ, K. and MANAI, A. G. E., 2009. Le differenze e le somiglianze culturali come fonte di malintesi comunicativi tra italiano e slovacco. In: M. Arcangeli, ed. Lingua italiana d'oggi. Roma: Bulzoni Editore, pp. 369-380.

KÖVECSES, Z., 2002. Metaphor: A practical introduction. Oxford: Oxford University Press. 
LAKOFF, G., 1987. Women, fire, and dangerous things. What categories reveal about the mind. Chicago and London: The University of Chicago Press.

LUQUE DURÁN, J. D., 2009. Estereotipos, automatismos y juegos del lenguaje en el Diccionario Cultural. In: L. Luque Toro, ed. Léxico Español Actual II, Venezia: Cafoscarina, pp. 109-130.

McGEE, R. J. and WARMS, R. L. eds., 2013. Theory in social and cultural anthropology: An encyclopedia. Los Angeles: SAGE.

MILLS, S., 2008. Language and sexism. Cambridge: Cambridge University Press.

OAKLEY, A., 2000. Pohlaví, gender a společnost. Praha: Portál.

PAJDZIŃSKA, A., 2007. Kategorie strukturující jazykový obraz světa: antropocentrismus a opozice "vlastní" - "cizí". In: L. Saicová Římalová, ed. Čítanka textů z kognitivní lingvistiky II. Praha: Univerzita Karlova, pp. 27-44.

SAPIR, E., 1921. Language: An introduction to the study of the speech. New York: Harcourt, Brace and Company.

SAPIR, E., 2008. The status of linguistics as a science (1929). In: P. Swiggers, ed., The collected works of Edward Sapir. 1, General linguistics. Berlin and New York: Mouton de Gruyter, pp. 219-226.

SCHOLZE-STUBENRECHT, W., 2008. Duden. Band 11, Redewendungen. Wörterbuch der deutschen Idiomatik. Mannheim and Zürich: Dudenverlag. [DUDEN 11]

SECO, M., et al., 2006. Diccionario fraseológico documentado del español actual: locuciones y modismos españoles. Madrid: Santillana. [DFEA]

VALEŠ, M., 2010. Observaciones sociolingüísticas del español. Metodología, variación y prestigio. Saarbrücken: LAP LAMBERT Academic Publishing.

VAŇKOVÁ, I., 2010. Úvodem: na cestě ke kognitivní (etno)lingvistice. Slovo a slovesnost, no.4, pp. 245-249.

WALTER, E., ed., 2002. Cambridge nternational ictionary of dioms. Cambridge: Cambridge University Press. [CIDI]

WHORF, B. L., 1978. Science and linguistics (1940). In: J. B. Carroll, ed. Language, thought and reality. Selected writings of Benjamin Lee Whorf. Cambridge: M.I.T, pp. 207-219.

ZINKEN, J., 2004. Metaphors, stereotypes, and the linguistic picture of the world: Impulses from the Ethnolinguistic School of Lublin. metaphorik.de 7, pp. 115-136.

\author{
Author's address and contact details \\ Dr. Enrique Gutiérrez Rubio \\ Palacký University in Olomouc \\ Filozofická fakulta \\ Katedra romanistiky \\ Kř́žkovského 10 \\ 77180 Olomouc \\ Czech Republic \\ Phone number: 00420585633347 \\ E-mail: egutierrez.rubio@gmail.com
}

